\title{
THE EMPIRICAL STUDY OF ANTECEDENTS AND CONSEQUENCES OF EMPLOYER BRANDING IN THAI-LISTED FIRMS
}

Sumittra Jirawuttinunt, Mahasarakham Business School, Mahasarakham University, Thailand Kannika Janepuengporn, Mahasarakham Business School, Mahasarakham University, Thailand

\author{
dx.doi.org/10.18374/EJM-13-4.5
}

\begin{abstract}
The research aims at examining the relationships between employer branding (functional and emotional aspects) and organizational competitiveness via talent management effectiveness and organizational attractiveness. It also explores the antecedent effects of employer branding. The model is tested using data collected from mail survey questionnaires of 86 Thai-Listed firms. The results of OLS regression analysis indicate that employer branding has a significant influence on organizational competitiveness both direct and indirect through talent management effectiveness and organizational attractiveness. However, unexpectedly, the findings reveal that employer image and reputation does not influence any relationships. Potential discussion with the research results is effectively implemented in the research. Contributions, conclusion and directions of the future research are highlighted.
\end{abstract}

Keywords: Employer Branding, Talent Management Effectiveness, Organizational Attractiveness, Organizational Competitiveness 